\title{
Percutaneous injuries among healthcare workers at a general hospital
}

\author{
Ibak Gönen, Mehmet Faruk Geyik \\ Düzce University, Faculty of Medicine, Department of Infectious Diseases, Düzce, Türkiye
}

\begin{abstract}
Objectives: Percutaneous injuries (PCIs) remain a common incident among healthcare workers (HCWs) despite the introduction of safety programs. The aim of this study was to assess the PCIs, required precautions, and applications after the injuries among healthcare workers in a small general hospital.
\end{abstract}

Materials and methods: We assessed the occurrence of PCIs at a General Hospital (EGH) from January 2007 to November 2010. During this period, all injury cases among HCWs were reported to the Infection Control Committee (ICC) using percutaneous injury notification form. The injury notification forms were evaluated retrospectively.

Results: Totally 275 health personnel were working in our hospital, 36 healthy workers have been exposed to PCIs during this period. The incidence of PCIs was 2,9/10000 in 2007, 3,1/10000 in 2008, 3,8/10000 in 2009 and 3,9/10000 patient-days in 2010. Injured staff were recorded as, 16 nurses (44\%), 12 cleaning staffs (34\%), and eight (22\%) doctors. The device leading to damage was most frequently the needle-channel. Ten sources (27\%) were detected positive for hepatitis B virus (HBV), four (11\%) for hepatitis C virus (HCV), and two (5\%) for Crimean-Congo hemorrhagic fever virus (CCHFV). No case of seroconversion has been recognized for any of the above mentioned infections.

Conclusions: Percutaneous injuries remain to occur among HCWs. Since some the sources were infected, the health personnel are endangered for infections due to PCIs. The health personnel should presume that all patients are infected, and thus should work following universal precautions to avoid complications about the PCIs. J Microbiol Infect Dis 2011;1(1):26-30.

Key words: Percutaneous injuries, health workers, general state hospital

\section{Bir devlet hastanesi sağlık çalışanlarında perkütan yaralanmalar}

\section{ÖZET}

Amaç: Güvenlik programlarının devreye girmesine rağmen sağlık çalışanları arasında hala perkutanöz yaralanmalar yaygın olarak görülmektedir. Bu çalışmada, küçük bir devlet hastanesi sağlık çalışanlarında meydana gelen perkütan yaralanmaların değerlendirilmesi, alınacak önlemler ve yaralanma sonrası uygulanacak işlemlerin değerlendirilmesi amaçlanmıştır.

Gereç ve yöntem: Bir Devlet Hastanesi'nde Ocak 2007 ile Kasım 2010 arasında görülen perkutanöz yaralanmaları değerlendirdik. BU dönemde sağlık personeli arasında görülen tüm perkutanöz yaralanmalar ilgili formlar ile Enfeksiyon Kontrol Kkomitesi'ne bildirildi. BU çalışmada Perkutanöz yaralanma formları retrospektif olarak incelendi.

Bulgular: Hastanede toplam 275 sağlık personeli çalışmakta olup, bu süre zarfında 36 (\%13) personelde perkütan yaralanma maydana geldi. Perkutanöz yaralanma sıkığı 2007, 2008,i 2009 ve 2010 yılları için sırasıyla 10,000 hastagün'de 2.9, 3.1, 3.8 ve 3.9 olarak saptandı. Yaralananların 16'sı (\% 44) hemşire, 12'si (\%34) temizlik personeli, sekizi (\%22) ise doktordur. Yaralanmaya en sık neden olan alet kanallı iğnelerdir. Kaynakların on tanesinde hepatit B virüsü (HBV), dördünde hepatit $C$ virüsü (HCV), iki kaynakta ise Kırım-Kongo kanamalı ateşi virüsü (KKKAV) pozitifliği tespit edilmiştir. Hiçbir sağlık personelinde adı geçen infeksiyonlar için serokonversiyon gelişmedi.

Sonuç: Perkutan yaralanmalar sağlık çalışanlarında hala yaygın olarak görülmektedir. Kaynakların bazısının enfekte olması, sağlık çalışanlarının perkütanöz yaralanmalar neticesinde bulaşan enfeksiyonlar açısından büyük risk altında olduğunu göstermektedir. Sağlık çalışanları tüm hastaları enfekte kabul edip evrensel önlemlere uyarak çalışmalı ve yaralanmalardan korunmak için evrensel önlemlere uymalıdırlar.

Anahtar Kelimeler: Perkütan yaralanma, sağılı çalışanları, genel devlet hastanesi 


\section{INTRODUCTION}

Healthcare workers (HCWs) may be exposed to various infectious agents while practicing their profession especially in case of percutaneous injuries (PCls). The infectious agents may be transmitted via the respiration-droplet route and contact or the parenteral route. While parenteral transmission commonly occurs as a result of needle stick and sharp injuries, the contact of the skin and mucosa with impaired integrity to the infected material may also occasionally lead to transmission. Any microorganism present in the blood may be transmitted to the injured person via this route. To date, more than 20 agents transmitted through such injuries have been reported..$^{1,2}$ However, the most significant agents include the hepatitis $B$ virus (HBV), hepatitis C virus (HCV) and the human immunodeficiency virus (HIV) due to their potential to result in systemic infection and become chronic. ${ }^{3}$ Crimean-Congo Hemorrhagic fever (CCHFV), a virus that has started to be more commonly observed in our country in recent years, may be included in this category when considering Turkey due to the fact that it may lead to fatal infections.

The application of universal precautions (UP) has been shown to reduce the number of $\mathrm{PCl}$ s and related infections. In many countries, the use of protective measures is now mandatory for HCWs with a potential for occupational risk. According to new safety rules, all hospitals have to have an occupational management program. Some studies have reported that the risk of occupational PCls from blood-borne pathogens is a serious problem for Turkish HCWs. It is well acknowledged that the effectiveness of these programs depends on the compliance and adherence to UP standards by hospital management and HCWs. On the other hand, the data about the incidence of PCls in hospitals could be helpful to understand exact situation in Turkey. This study aims to evaluate occurrence of $\mathrm{PCl}$ episodes in a small hospital.

\section{MATERIALS AND METHODS}

This study was performed at Erbaa General Hospital between 2007 and 2010. Erbaa General Hospital is a 150-bed hospital providing service with $275 \mathrm{HCWs}$. As of 2010 December, the work distribution is as follows: 36 physicians, 152 nurs- es-midwifes, health officers and emergency medical technicians, 22 laboratory-x-ray technicians, and 65 cleaning staff from a private company. The hospital has an infection control program which runs by the Infection Control Committee (ICC). The committee started a follow-up program to monitor PCls among HCWs in the beginning of 2007. All PCls were reported to the ICC during the study period. These forms included data on the patient's name, surname, gender, occupation, department of employment, the instrument causing the percutaneous injury, the activity during which the injury occurred, the type of contact, the serologic status of the contacting HCWs, the serologic status if the source is known, the reporting period of the contact and whether prophylaxis was administered after the contact.

In a retrospective approach, the injury follow-up forms between 2007 and 2010 were retrospectively evaluated. The incidence of PCls was calculated that the number of incidence was accepted as numerator and the 10,000-patient-day.

\section{RESULTS}

Between 2007 and 2010, 36 cases of percutaneous injuries were reported to the ICC. The evaluation of these individuals exposed to contact through their occupation revealed that 16 $(44 \%)$ contacts occurred in nurses, $12(34 \%)$ in the cleaning staff, and $8(22 \%)$ in the physicians. Six $(38 \%)$ of the 16 nurses were working in the surgical divisions; six (38\%) were working in the internal departments while four $(25 \%)$ were working in the emergency room. All eight $(100 \%)$ of the physicians exposed to percutaneous injury were working in the surgical departments. The source was detected in $24(67 \%)$ of the 36 contacts; 10 patients $(\% 27)$ were detected to have positive HBsAg, four patients (11\%) were detected to have positive anti-HCV, and two patients $(5 \%)$ were observed to be under monitoring due to CCHF. Positive HIV was not detected in any of the sources. The type of injury, distribution by staff, and the activity during which the injury occurred are summarized in Table 1 and Table 2.

The incidence of percutaneous injuries was $2,9 / 10000$ in $2007,3,1 / 10000$ in $2008,3,8 / 10000$ in 2009 and 3,9/10000 patient-days in 2010 .

While 22 of the healthcare workers exposed to percutaneous injuries immediately presented 
to the infection control physician or nurse following the injury, 14 healthcare workers presented within the first 24 hours after the injury.

Table 1. Features of percutaneous injuries.

\begin{tabular}{lcccc}
\hline Cause of percutaneous injury & \multicolumn{4}{c}{ The occupational groups } \\
\cline { 2 - 5 } & Doctor & Nurse & $\begin{array}{c}\text { Cleaning } \\
\text { staff }\end{array}$ & Total \\
\hline $\begin{array}{l}\text { Channel needles (syringes, } \\
\text { catheters, etc.) }\end{array}$ & 0 & 16 & 12 & 28 \\
$\begin{array}{l}\text { Ducted medical device (the tip } \\
\text { of a scalpel, suture needle) }\end{array}$ & 8 & 0 & 0 & 8 \\
\hline Total & 8 & 16 & 12 & 36 \\
\hline
\end{tabular}

Table 2. The activities during the percutaneous injuries.

\begin{tabular}{lc}
\hline The activity during which the injury occurred & Number (\%) \\
\hline During the end of the sheath off the needle & $7(19)$ \\
During opening the vascular access & $4(11)$ \\
During blood collection & $3(8)$ \\
During after the procedure the materials collection & $2(5)$ \\
During suturing & $8(22)$ \\
During garbage collection & $12(33)$ \\
\hline Total & 36 \\
\hline
\end{tabular}

Four healthcare workers, who were non-vaccinated or detected to have inadequate antibody response to HBV based on laboratory investigations, were administered hepatitis B immunoglobulin (if the source HBsAg was positive) at a dose of $0.06 \mathrm{ml} / \mathrm{kg}$ and a hepatitis $B$ vaccination within the first 24 hours, and exhibited no complications during follow-up. None of the four healthcare workers exposed to HCV containing blood developed HCV infection on follow-up. One of the two healthcare workers exposed to CCHF positive blood was administered prophylaxis with ribavirin at a dose of $4 \times 500 \mathrm{mg}$ while the other was not. None of them developed CCHF. In cases where the source was not detected, the employees were monitored for HBV, HCV and HIV infection with no emergent complications.

\section{DISCUSSION}

Present study demonstrated that a considerable portion of healthcare workers are exposed to percutaneous injuries while practicing their profes- sion. The World Health Organization reports that three million healthcare providers are exposed to blood-borne infections annually. As a result of this exposure, it has been estimated that annually 16,000 healthcare workers will develop HCV, 66,000 will develop HBV, and 1000 will develop HIV. $^{4}$ The type of injury, the type of instrument causing the injury, the presence of blood on the instrument, the diameter of the needle lumen, the viral load of the source and the immune status of the host are involved in the transmission of infection to healthcare providers following percutaneous contact. In cases of percutaneous injuries, the risk of transmission of the infectious agent is higher compared to contact with the mucous membrane. In cases of injury with instruments such as lancets and suture needles, the amount of inoculum is small while injuries from lumen needles and catheters involve an increased amount of inoculum and transmission risk. ${ }^{5} \mathrm{Al}-$ though it may vary depending on the viral load of the source, the mean risk of transmission following percutaneous contact is $6-30 \%, 3-10 \%$ and $0.3 \%$ for HBV, HCV and HIV, respectively. ${ }^{6}$ This rate is reported to be $33 \%$ for CCHF.

In this study, percutaneous injuries most commonly occurred in nurses. Yildirim et al reported the highest rate of injury among the nurses in their study where they investigated 44 percutaneous contacts. ${ }^{7}$ In a study by Merih et al, the rate of contact was highest among the cleaning staff. ${ }^{8}$ A cross-sectional study involving 860 nurses reported that $62.7 \%$ of the nurses had experienced at least one needle stick and sharp injuries within the previous three months. ${ }^{9}$ Various other studies also demonstrated that nurses most commonly sustained percutaneous injuries. ${ }^{10}$ In this study, the injuries occurred during closure of the needle cap (19\%), vascular access $(11 \%)$, and blood sampling (8\%) among nurses. In the case of the physicians, all injuries occurred during suturing $(22 \%)$, while the cleaning staff sustained injuries during garbage collection (33\%). A study investigating 200 percutaneous injuries reported that $31.7 \%$ of the injuries occurred during suturing, $21.6 \%$ during surgery, $13.8 \%$ during blood sampling, $13.4 \%$ during vascular access, $13.2 \%$ during injection and $6.3 \%$ during closure of the needle cap. ${ }^{11} \mathrm{~A}$ study by Altiok et al reported that the nurses sustained injuries most commonly during blood sampling, vascular access and closure of the needle cap. ${ }^{12}$ Gucuk et al reported that the 
nurses sustained injuries most commonly during breaking of the ampoules and that only $7.5 \%$ of the injuries occurred during closure of the needle cap. ${ }^{13}$ There are various studies demonstrating that the physicians sustained injuries during suturing, as is the case in this study. ${ }^{12-14}$ The type of injury sustained by the cleaning staff was observed to be similar to that reported in the other studies. ${ }^{8}$ It is important for the injured healthcare staff to present to the infection control physician or nurse without delay so that in turn prophylactic treatment can be initiated without delay. This study revealed that the 22 injuries $(61 \%)$ occurring during working hours were immediately reported while 14 injuries (39\%) occurring during shift hours were reported within 24 hours. While instructions on the procedures to be performed in case of percutaneous injury together with the 24-hour contact person data exist, the healthcare staff was not aware of these instructions, revealing the necessity to focus on these procedures during periodic trainings. Early initiation of the immunoglobulin administration to be performed in case of HBsAg positive blood contact and of the antiretroviral prophylaxis in case of HIV positive blood contact is important with respect to efficacy. In this study, among the patients on whom instruments that caused the injury were used, $10(28 \%)$ were detected to have positive HBsAg and four $(11 \%)$ were detected to have positive anti-HCV. A multi-center study reported an infected source rate of $28 \%$ in percutaneous injuries and HVC, HBV, HIV and multi viral factors were detected respectively in $63 \%, 13 \%, 11 \%$ and $13 \%$ of these. ${ }^{15}$ A study by Yildirim et al reported that 10 of the sources were $\mathrm{HBsAg}$ positive and 10 were $\mathrm{HCV}$ positive in 44 cases of contact. ${ }^{7}$ The fact that a vast majority of the sources are infected suggests that these injuries are reported only in cases where the sources are considered to carry a high risk. In this study, 36 percutaneous contacts were reported over a four-year period; Yıldırım et al reported 44 contacts while Merih et al reported 57 percutaneous contacts in their study over a three year period. ${ }^{7,8}$ Yet, the cross-sectional study has demonstrated that a majority of healthcare providers are exposed to percutaneous injuries. In a study by Kisioglu involving 450 healthcare staff, the incidence of needle stick and sharp injuries was reported to be $36.2 \%$ within the previous one year. ${ }^{16}$ In another study involving 1025 nurses, $67.2 \%$ of the nurses were reported to have sus- tained needle stick and sharp injuries within the previous three months. ${ }^{9}$ In the study by Altıok et al involving 956 healthcare workers, they reported that $79.1 \%$ of the healthcare workers were exposed to percutaneous injury at some time in their professional life. ${ }^{12}$ Considering these studies, it is a fact that a majority of these contacts are not reported and recorded. ${ }^{17,18} \mathrm{~A}$ study also reported that a vast majority of the percutaneous injuries in their subjects were not reported, and established a reporting rate of $51 \%$ for nurses and a reporting rate of $6 \%$ for the physicians. ${ }^{19}$ In the case of percutaneous injury, the site of contact should first be thoroughly washed with water and soap. In case of contact with the eyes, the eyes should be rinsed with saline, and the nose and the mouth thoroughly washed with water. The follow-up and the procedures should be performed following the exposure according to guidelines. ${ }^{7,20,21}$

In needle stick and sharp injuries, the most significant and effective procedure is that which is aimed at preventing these injuries. The activities of the hospital infection control committees are important. Health cards should be created for all workers, and the appropriate vaccinations administered and monitored. In addition, the whole staff, including the cleaning staff, should receive periodic training for percutaneous injuries. Twenty-four-hour contact persons whom the staff can reach in case of such exposure should be determined, and the necessary follow-up and treatments administered without delay. Relevant instructions should be established and submitted to all the departments.

In conclusion, we believe that the best method with which to minimize percutaneous injuries and secondary complications is for healthcare workers to consider all patients as infected individuals and practice accordingly, following global measures.

\section{REFERENCES}

1. Collins $\mathrm{CH}$, Kennedy DA. Microbiological hazards of occupational needlestick and sharps injuries. J Appl Bacteriol 1987;62:385-402.

2. Willy ME, Dhillon GL, Leowen NL Wesley RA, Henderson DK. Advers exposures and universal precautions practices among a group of highly exposed health professionals. Infect Control Hosp Epidemiol 1990;11: 351-356.

3. Dokuzoğuz B. Kontamine delici ve kesici aletlerle bulaşan infeksiyonlar ve önlemler. Hastane İnfeksiyonları Dergisi 1999; 3: 235-239. 
4. Pruss Ustun A, Rapiti E, Hutin Y. Estimation of the global burden of diseases attributable to contaminated sharps injuries among healthcare workers. Am J Ind Med 2005; 48: 482490.

5. Aygün P. Delici ve kesici alet yaralanmaları ve korunma önlemleri. In; The book of 5th National Sterilization and Disinfection congress 2007;385-391.

6.Usluer $\mathrm{G}$. Viral hepatitler ve kan yoluyla bulaşan infeksiyonlar. 'Günaydın M, Esen Ş, Saniç A, Leblebicioğlu H (eds): In; the book of, Sterilization Disinfection and Hospital Infections, Simad Publications, Samsun: 2002; 269-278.

7. Yıldırım M, Şencan İ, Özdemir D, Yılmaz Z, Küçükbayrak A, Çakır S. Assesment of risky exposures to HBV and HCV in health care workers and cost analysis. Viral Hepatit Dergisi 2005;10:139-143.

8. Merih YD, Kocabey MY, Çırpı F, Bolca Z, Celayir AC. Epidemiology and preventive measurements of sharp injuries in a state hospital during the last three years. Zeynep Kamil Tıp Bülteni 2009;40:11-15.

9. Omaç M, Eğri M, Karaoğlu L. Evaluation of occupational needlestick-sharp injuries and status of hepatitis B immunization on nurse working at Malatya province hospitals. İnönü Üniversitesi Tıp Fakültesi Dergisi 2010;17: 19-25.

10. Popejoy SL, Fry DE. Blood contact and exposure in the operating room. Surg Gynecol Obstet1991;172: 480-483.

11. Salelkar S, Motghare DD, Kulkarni MS, Vaz FS. Study of needle stick injuries among health care workers at a tertiary care hospital. Indian J Public Health. 2010; 54:18- 20.

12. Altıok M, Kuyurtar F, Karaçorlu S, Ersöz G, Erdoğan S. Healthcare workers experiences witk sharps and needlestick injuries and precautions they took when injuries. Maltepe Üniversitesi Hemşirelik Bilim ve Sanatı Dergisi 2009;2: 7079.

13. Gücük M, Karabey S, Yolsal N, Irmak Özden Y. Percuteneous injuries in the health care personnel working in the general surgery clinics of the medical school of Istanbul. Hastane İnfeksiyonları Dergisi 2002;6: 72-81.

14. Tokars JI, Bell DM, Culver DH, Marcus R, Mendelson $\mathrm{MH}$, Sloan EP, Farber BF, Fligner D, Chamberland ME, McKibben $P S$, et al. Percutaneous injuries during surgial procedures. JAMA 1992;267: 2899-2904.

15. Ippolita G, Puro V, Petrosilla N, De Carli G. Surveiilance of occupational exposure blood borne pathogens in healthcare workers: the Italian national programme. Euro Surveill. 1999; 4:33-36.

16. Kişioğlu N, Öztürk M, Uskun E, Kırbıyık S. In a medical hospital's health workers incisive and perforating injury epidemiologies and prevention behaviors and attitudes. T Klin Med Sci 2002;22:390-396.

17. Moloughney BW. Transmission and postexposure management of bloodborne virus infections in the health care setting: Where are we now? Can Med Assoc J 2001;165: 445-451.

18. Sencan I, Sahin I, Yıldırım M, Yesildal N. Unrecognized abrasions and occupational exposures to bloodborne pathogens among healthcare workers in Turkey. Occupational Medicine 2004;54: 202-206.

19. Husgy AM, Minde T, Knudsen H, Aks-elsen PE. Needlestick injuries and reporting routines. Tidsskr Nor Laegeforen 2010; 130:735-737.

20. Dokuzoğuz B. İnfeksiyon kontrolü ve personel sağlığı, sağlık çalışanlarının yaralanma ve infeksiyondan korunması. Doğanay M, Ünal S (eds). In; The book of Hospital Infections, 'Bilimsel Tıp' Publications 2003, Ankara:375-389.

21. Doyuk Kartal E. Sağıık personelinde profilaksi. İ.Ü Cerrahpaşa Tıp Fakültesi sürekli tıp eğitimi etkinlikleri: In; The book of Toplumdan edinilmiş infeksiyonlara pratik yaklaşımlar' 2008; 215-222.

22. Ergonul O. Crimean-Congo Hemorrhagic Fever. Lancet Infect Dis 2006; 6:203-214. 